\title{
Article/Artigo
}

\section{Prevalence of Neisseria gonorrhoeae and Chlamydia trachomatis infection in men attending STD clinics in Brazil}

\author{
Prevalência de Neisseria gonorrhoeae e infecção pela Chlamydia trachomatis em homens \\ atendidos em clínicas de DST no Brasil
}

\author{
Marcelo Joaquim Barbosa ${ }^{1,3}$, Fabio Moherdaui ${ }^{2}$, Valdir Monteiro Pinto ${ }^{1,3}$, Denis Ribeiro ${ }^{1,3}$, Marcos Cleuton ${ }^{2}$ \\ and Angelica Espinosa Miranda ${ }^{3}$
}

\begin{abstract}
Introduction: The study aimed to assess the prevalence of Neisseria gonorrhoeae and Chlamydia trachomatis infections and identify demographic, behavioral and clinical factors correlated with such infections in men attending six sexually transmitted disease clinics in Brazil. Methods: Multicentric, cross-sectional study performed among men attending STD clinics in Brazil. The study included STD clinics in six cities distributed throughout the five geographic regions of Brazil in 2005. Patients provided $20 \mathrm{ml}$ of first catch urine for testing for NG and CT by DNA-PCR. Results: A total of 767 (92.9\%) men were included in the study. The mean age was 26.5 (SD 8.3) years-old. Prevalence of Chlamydia infection was $13.1 \%$ (95\%CI 10.7\%-15.5\%) and gonorrhea was $18.4 \%$ (95\%CI 15.7\%$21.1 \%)$. Coinfection prevalence was $4.4 \%$ (95\% CI 2.95\%-5.85\%) in men who sought attendance in STI clinics. Factors identified as associated with C. trachomatis were younger age (15-24) $[\mathrm{OR}=1.4(95 \% \mathrm{CI} 1.01-1.91)]$, present urethral discharge $[\mathrm{OR}=4.8(95 \% \mathrm{CI} 1.52-15.05)]$, genital warts $[\mathrm{OR}=3.0(95 \% \mathrm{CI} 1.49-5.92)]$ and previous history of urethral discharge $[\mathrm{OR}=2.4(95 \% \mathrm{CI}$ 1.11-5.18)]. Variables associated with gonorrhea were younger age (15 to 24$)$ [OR=1.5 (95\%CI 1.09-2.05) $]$, presence of urethral discharge $[\mathrm{OR}=9.9(95 \% \mathrm{CI} 5.53-17.79)]$, genital warts $[\mathrm{OR}=18.3$ (95\%CI 8.03-41.60) ] and ulcer present upon clinical examination [OR=4.9 (95\%CI 1.06-22.73)]. Conclusions: These findings have important implications for education and prevention actions directed toward men at risk of HIV/STD. A venue-based approach to offer routine screening for young men in STD clinics should be stimulated.
\end{abstract}

Key-words: Chlamydia trachomatis. Neisseria gonorrhoeae. Risk factors. Multicentric study. STD clinic. PCR

\section{RESUMO}

Introdução: Nosso objetivo foi acessar a prevalência de Neisseria gonorrhoeae e Chlamydia trachomatis e identificar fatores demográficos, comportamentais e clínicos correlacionados a essas infecções em homens atendidos em clínicas de doenças sexualmente transmissíveis no Brasil. Métodos: Estudo multicêntrico, transversal conduzido em homens que procuraram atendimento em clínicas de DST. O estudo incluiu clínicas de DST em seis cidades distribuídas nas cinco regiões geográficas do Brasil em 2005. Pacientes coletaram 20ml do primeiro jato de urina para testar NG e CT por DNA-PCR. Resultados: Um total de 767 (92,9\%) homens foi incluído no estudo. A média de idade foi 26,5 (DP 8,3) anos. A prevalência de infecção por CT foi 13,1\% (IC95\% $10,7 \%-15,5 \%$ ) e NG de $18,4 \%$ (IC95\% 15,7\%-21,1\%). A prevalência de co-infecção foi 4,4\% (IC95\% 2,95\%-5,85\%). Os fatores identificados como sendo associados com a infecção pela CT foram ser jovem $(15-24)$ [OR=1,4 (IC95\% 1,01-1,91)], apresentar corrimento uretral ao exame $[\mathrm{OR}=4.8(\mathrm{IC} 95 \%$ 1,52-15,05)], verrugas genitais $[\mathrm{OR}=3,0(\mathrm{IC} 95 \% 1,49-5,92)]$ e história prévia de corrimento uretral $[\mathrm{OR}=2,4$ (IC95\% 1,11-5,18)]. As variáveis associadas com a gonorréia foram ser jovem (15 to 24$)[\mathrm{OR}=1,5$ (IC95\% 1,09-2,05)], apresentar corrimento uretral $[\mathrm{OR}=9,9$ $(\mathrm{IC} 95 \% 5,53-17,79)]$, verrugas genitais $[\mathrm{OR}=18,3$ (IC95\% 8,03-41,60)] e úlcera ao exame clínico $[\mathrm{OR}=4,9$ (IC95\% 1,06-22,73)]. Conclusões: Estes resultados têm implicações importantes para medidas de educação e prevenção direcionadas aos homens com risco acrescido de HIV/DST. A abordagem no serviço para oferecer testes de rotina para homens jovens atendidos em clínica de DST deve ser estimulada.

Palavras-chaves: Chlamydia trachomatis. Neisseria gonorrhoeae. Fatores de risco. Estudo multicêntrico. Clínicas DST. PCR.

1. STD Unit, National Department of STD/AIDS and Viral Hepatitis, Ministry of Health, Brasília, DF, Brazil. 2. Surveillance Unit, National Department of STD/AIDS and Viral Hepatitis, Ministry of Health, Brasília, DF, Brazil. 3. Infectious Diseases Unit, Federal University of Espírito Santo, Vitória, ES, Brazil. Address to: Dra. Angelica Espinosa Miranda. NDI/UFES. Av. Marechal Campos 1468 Maruípe, 29043-900 Vitória, ES.

Phone: 5527 3335-7210; Fax: 5527 3335-7504

e-mail: espinosa@ndi.ufes.br

Received in $17 / 02 / 2010$

Accepted in 13/07/2010

\section{INTRODUCTION}

The importance of understanding and addressing Chlamydia trachomatis (CT)infections and gonorrhea among men is being recognized in several studies ${ }^{1,2}$. The role of identifying and treating male infections in preventing adverse outcomes among women has prompted some researchers to call for Chlamydia trachomatis and gonorrhea screening guidelines directed at detecting male infections $s^{3,4}$.

Untreated infections may have direct adverse outcomes among men, including epididymitis, prostatitis and proctitis ${ }^{4,5}$. Currently, males are opportunistically tested for C. trachomatis infection and/or gonorrhea; recommendations for routinely screening males for these infections are discouraged ${ }^{1}$. Although several existing studies have examined Chlamydia and gonorrhea infections in men, these studies are geographically limited, targeted to a certain portion of the population ${ }^{6-9}$.

Sexually transmitted disease (STD) Treatment Guidelines of the Centers for Disease Control and Prevention (CDC) recommend empirical treatment for $C$. trachomatis when treating a diagnosed gonococcal infection, because Chlamydia coinfection is frequent among individuals diagnosed with gonorrhea ${ }^{4}$. Frequently, coinfection data are derived from STI clinic settings, where patients are likely to present with symptoms of, or suspected exposure to, an STD ${ }^{10}$.

National published data regarding C. trachomatis infections and gonorrhea among men in Brazil is not available, while prevalence date for these infections are available only in local studies ${ }^{11,12}$. In this study, the prevalence of Neisseria gonorrhoeae (NG) and Chlamydia trachomatis infection and the coinfection rate were assessed and correlated demographic, behavioral and clinical factors were identified in an at-risk population during a multicentric study among men attending STD clinics in six cities in Brazil distributed among the five geographical regions. The information will be used for planning prevention and assistance programs to reach this population. 


\section{METHODS}

A multicentric, cross-sectional study conducted among men attending STD clinics in Brazil. The study included STD clinics in six geographically diverse cities in Brazil (São Paulo, Rio de Janeiro, Porto Alegre, Goiânia, Fortaleza and Manaus) in 2005.

\section{Population}

Men seeking care during their first visit to a STD clinic and with no history of antibiotic therapy in the preceding 15 days were invited to take part in the study. HIV positive men were excluded.

\section{Sample size}

Based on a priori power calculations, the study required the enrollment of 750 men to provide $80 \%$ power to estimate a point prevalence of Chlamydia and gonorrhea coinfection at $5 \%{ }^{11}$ with a $95 \%$ confidence interval of (3.5\%-6.5\%). Considering a refusal rate of $10 \%, 825$ men were required. All men sampled who met the eligibility criteria were invited to participate.

\section{Subject selection and eligibility criteria}

Health professionals invited men attending STD clinics for the first time to take part in the study. At the time of screening, all men in the multicentric study were asked to complete a standard questionnaire involving demographic, behavioral and clinical data, including STD symptoms. Those who accepted screening provided a urine specimen. Gonorrhea and/or Chlamydia infected men were notified and treated according to the Brazilian National STD guidelines ${ }^{13}$. Patients received counseling to advise all their sexual partners in order to provide testing and treatment. Determination of research-exempt status or human subjects review and approval was obtained from all participating institutions. Free, informed consent was obtained and patient confidentiality was maintained, as required by law.

\section{Laboratory specimens}

Patients provided $20 \mathrm{ml}$ of first catch urine to test for Neisseria gonorrhoeae and Chlamydia trachomatis by DNA detection using Polymerase Chain Reaction (PCR; Cobas Amplicor CT/NG, Roche Diagnostics Systems, USA). These tests are the most sensitive available.

\section{Statistical analysis}

Standard descriptive statistical analyses were performed, including frequency distributions for categorical data and calculation of means and standard deviations for continuous variables. Prevalence of coinfection was defined as the detection of both Neisseria gonorrhoeae and Chlamydia trachomatis in a single urine specimen. It was calculated to reflect its relative frequency, with corresponding $95 \%$ confidence intervals (95\% CI). Odds ratios and $95 \% \mathrm{CI}$ were calculated in bivariate analyses to estimate the strength of the association between infections and each potential risk factor. Independent risk factors for each infection were assessed using stepwise logistic regression: variables significant at $P 0.05$ in bivariate analysis were entered into the model and additional variables were entered into the multivariate model based on known a priori associations (for instance, age and number of sex partners).

\section{Ethical}

The Ethics in Research National Committee approved the protocol for the study. Written, informed consent was obtained by all participants and their parents or guardians (if $<18$ years), in accordance with Brazilian legal guidelines.

\section{RESULTS}

A total of 767 (92.9\%) men were included in the study. The mean age was 26.5 (SD 8.3) years-old. The global prevalence of $C$. trachomatis infection was $13.1 \%$ (95\%CI $10.7 \%-15.5 \%)$ and gonorrhea was $18.4 \%$ (95\% CI 15.7\%-21.1\%). Coinfection prevalence was 4.4\% (95\%CI 2.95\%-5.85\%) in men who sought attendance at STD clinics.

Table 1 shows the correlations between demographic characteristics and STD prevalence: $52.4 \%$ of men were 15 to 24 years-old, $55.4 \%$ had nine or more years of education, $59.8 \%$ were single and $73.5 \%$ earned a monthly income of four or less Brazilian minimum wages (1 Brazilian minimum wage $=$ US $\$ 150$ in 2005). The only correlation was between C. trachomatis infection and age from 25 to 34 years-old.

TABLE 1 - Prevalence of Neisseria gonorrhoeae and Chlamydia trachomatis infections and their correlation with demographic factors among men attending STD clinics in six cities in Brazil, 2005 ( $n=767)$.

\begin{tabular}{|c|c|c|c|c|c|c|}
\hline \multirow[b]{2}{*}{ Variables } & \multicolumn{3}{|c|}{ CT $(n=101)$} & \multicolumn{3}{|c|}{ GC $(n=141)$} \\
\hline & $\mathrm{n}$ & $\%$ & OR $(95 \% \mathrm{CI})$ & $\mathrm{n}$ & $\%$ & OR $(95 \% \mathrm{CI})$ \\
\hline \multicolumn{7}{|l|}{ Age in years } \\
\hline up to 24 & 53 & 13.2 & $1.8(0.88-3.85)$ & 80 & 19.9 & $1.7(0.94-3.09)$ \\
\hline 24 to 34 & 39 & 15.8 & $2.3(1.06-4.86)$ & 46 & 18.6 & $1.6(0.84-2.95)$ \\
\hline 35 or older & 9 & 7.6 & 1 & 15 & 12.7 & 1 \\
\hline \multicolumn{7}{|l|}{ Education } \\
\hline up to 4 years & 12 & 14.1 & $(0.56-2.17)$ & 17 & 20.0 & $1.1(0.59-1.90)$ \\
\hline 5 to 8 & 34 & 13.2 & $(0.65-1.62)$ & 43 & 16.7 & $0.9(0.57-1.28)$ \\
\hline nine or more & 55 & 12.9 & 1 & 81 & 19.1 & 1 \\
\hline \multicolumn{7}{|l|}{ Marital status } \\
\hline married/living together & 27 & 10.2 & $0.8(0.30-2.31)$ & 39 & 14.7 & $(0.41-2.61)$ \\
\hline single & 69 & 15.0 & $(0.50-3.45)$ & 96 & 20.9 & $1.59(0.65-3.89)$ \\
\hline divorced/widow & 5 & 11.9 & 1 & 6 & 14.3 & 1 \\
\hline \multicolumn{7}{|l|}{ Monthly income* } \\
\hline$<2$ minimal wage & 23 & 14.1 & $(0.55-1.79)$ & 36 & 22.1 & $(0.74-2.06)$ \\
\hline 2 to 4 minimal wage & 49 & 12.3 & $0.8(0.51-1.38)$ & 67 & 16.8 & $0.9(0.57-1.36)$ \\
\hline 5 or more & 29 & 14.2 & 1 & 38 & 18.6 & 1 \\
\hline
\end{tabular}

*One Brazilian minimal wage in 2005 = US\$150. CT: Chlamydia trachomatis, GC: Neisseria gonorrhoeae.

Regarding risk behaviors, 339 participants reported first sexintercourse at $\leq 14$ years of age, $85.4 \%$ reported one partner in the preceding 12 months, $20.1 \%$ reported regular use of condoms and $13.4 \%$ reported injecting drug use. Having one sexual partner in the preceding 12 months had a negative correlation with a diagnosis of gonorrhea (Table 2).

Table 3 describes clinical symptoms; previous history of genital warts was correlated with Chlamydia trachomatis and Neisseria gonorrhoeae and having a sexual partner with a genital ulcer was correlated with gonorrhea. In clinical examinations, presenting urethral discharge, genital ulcers and genital vesicles were associated with Chlamydia trachomatis and Neisseria gonorrhoeae infections.

Factors identified as being independently associated with Chlamydia trachomatis in the final multiple logistic model were younger age $(15-24)[\mathrm{OR}=1.4(95 \% \mathrm{CI} 1.01-1.91)]$, presence of urethral discharge $[\mathrm{OR}=4.8(95 \% \mathrm{CI} 1.52-15.05)]$, genital warts $[\mathrm{OR}=3.0(95 \% \mathrm{CI} 1.49$ $5.92)]$ and previous history of urethral discharge $[\mathrm{OR}=2.4(95 \% \mathrm{CI} 1.11$ 5.18)]. Variables associated with Neisseria gonorrhoeae were younger age (15 to 24$)[\mathrm{OR}=1.5(95 \% \mathrm{CI} 1.09-2.05)]$, presence of urethral discharge $[\mathrm{OR}=9.9(95 \% \mathrm{CI} 5.53-17.79)]$, genital warts $[\mathrm{OR}=18.3(95 \% \mathrm{CI}$ $8.03-41.60)]$ and ulcer upon clinical examination $[\mathrm{OR}=4.9(95 \% \mathrm{CI}$ 1.06-22.73)] (Table 4). 
TABLE 2 - Prevalence of Neisseria gonorrhoeae and Chlamydia trachomatis infections and their correlation with behavioral factors among men attending STI clinics in six cities in Brazil, $2005(\mathrm{~N}=767)$.

\begin{tabular}{|c|c|c|c|c|c|c|}
\hline \multirow[b]{2}{*}{ Variables } & \multicolumn{3}{|c|}{ CT infection $(n=101)$} & \multicolumn{3}{|c|}{ GC $(n=141)$} \\
\hline & $\mathrm{n}$ & $\%$ & OR $(95 \% \mathrm{CI})$ & $\mathrm{n}$ & $\%$ & OR (95\%CI) \\
\hline \multicolumn{7}{|l|}{ Age at first sex } \\
\hline up to 14 years & 41 & 12.1 & $0.8(0.55-1.29)$ & 70 & 20.6 & $1.3(0.91-1.89)$ \\
\hline 15 or older & 60 & 14.0 & 1 & 71 & 16.6 & 1 \\
\hline \multicolumn{7}{|c|}{ Number of sex partners in last 12 months } \\
\hline one & 82 & 12.5 & $0.7(0.41-1.21)$ & 110 & 16.8 & $0.5(0.33-0.84)$ \\
\hline more than one & 19 & 17.0 & 1 & 31 & 27.7 & 1 \\
\hline \multicolumn{7}{|c|}{ Regular use of condoms } \\
\hline yes & 15 & 9.7 & $0.7(0.37-1.18)$ & 21 & 13.6 & $0.6(0.39-1.07)$ \\
\hline no & 86 & 14.0 & 1 & 120 & 19.6 & 1 \\
\hline \multicolumn{7}{|l|}{ MSM } \\
\hline yes & 47 & 12.6 & $0.9(0.59-1.37)$ & 73 & 19.5 & $1.2(0.80-1.67)$ \\
\hline no & 54 & 13.7 & 1 & 68 & 17.3 & 1 \\
\hline \multicolumn{7}{|l|}{ IDU } \\
\hline yes & 16 & 15.5 & $1.3(0.70-2.24)$ & 17 & 16.5 & $0.9(0.49-1.50)$ \\
\hline no & 85 & 12.8 & 1 & 124 & 18.7 & 1 \\
\hline
\end{tabular}

TABLE 3 - Prevalence of Neisseria gonorrhoeae and Chlamydia trachomatis infections and their correlation with clinical factors among men attending STI clinics in six cities in Brazil, $2005(\mathrm{~N}=767)$.

\begin{tabular}{|c|c|c|c|c|c|c|}
\hline \multirow[b]{2}{*}{ Variables } & \multicolumn{3}{|c|}{ CT $(n=101)$} & \multicolumn{3}{|c|}{ GC $(n=141)$} \\
\hline & $\mathrm{n}$ & $\%$ & OR $(95 \% \mathrm{CI})$ & $\mathrm{n}$ & $\%$ & OR $(95 \% \mathrm{CI})$ \\
\hline \multicolumn{7}{|c|}{ Previous symptoms of STI } \\
\hline urethral discharge & 86 & 13.5 & $1.2(0.67-2.15)$ & 110 & 17.3 & $1.1(0.42-1.25)$ \\
\hline genital warts & 61 & 17.8 & $2.1(1.36-3.20)$ & 93 & 27.2 & $2.9(1.99-4.30)$ \\
\hline genital ulcer & 24 & 10.5 & $0.7(0.43-1.15)$ & 26 & 11.4 & $0.5(0.30-0.75)$ \\
\hline genital vesicles & 17 & 11.4 & $0.8(0.47-1.43)$ & 18 & 12.1 & $0.6(0.33-1.00)$ \\
\hline \multicolumn{7}{|c|}{ Partner with STI symptoms } \\
\hline urethral discharge & 4 & 16.7 & $1.3(0.45-3.98)$ & 4 & 16.7 & $0.9(0.30-2.63)$ \\
\hline genital warts & 25 & 15.2 & $1.2(0.76-2.02)$ & 35 & 21.2 & $1.3(0.82-1.93)$ \\
\hline genital ulcer & 7 & 11.7 & $1.2(0.51-2.63)$ & 4 & 6.7 & $3.4(1.20-9.43)$ \\
\hline genital vesicles & 4 & 15.4 & $1.2(0.41-3.58)$ & 3 & 11.5 & $0.6(0.17-1.93)$ \\
\hline \multicolumn{7}{|l|}{ Physical examination } \\
\hline urethral discharge & 41 & 40.6 & $2.4(1.56-3.73)$ & 112 & 79.4 & $27.8(17.37-44.79)$ \\
\hline genital warts & 9 & 7.8 & $1.9(0.94-3.97)$ & 2 & 1.7 & $15.4(3.75-62.50)$ \\
\hline genital ulcer & 16 & 5.6 & $3.6(2.08-6.33)$ & 12 & 4.2 & $8.4(4.55-15.38)$ \\
\hline genital vesicles & 71 & 22.5 & $4.1(2.59-6.44)$ & 129 & 41.0 & $25.4(13.71-46.97)$ \\
\hline
\end{tabular}

CT: Chlamydia trachomatis, GC: Neisseria gonorrhoeae.

TABLE 4 - Multivariate analysis of factors associated with Neisseria gonorrhoeae and Chlamydia trachomatis infections among men attending STI clinics in six cities in Brazil, 2005 ( $N=767)$.

\begin{tabular}{lccc}
\hline Factors & Adjusted Odds Ratio & $95 \% \mathrm{CI}$ & P value \\
\hline \multicolumn{1}{c}{ Chlamydia trachomatis } & & & \\
Younger age (15-24 years) & 1.38 & $1.01-1.91$ & 0.048 \\
Urethral discharge upon physical examination & 4.78 & $1.52-15.05$ & 0.007 \\
Genital warts upon physical examination & 2.97 & $1.49-5.92$ & 0.002 \\
History of urethral discharge & 2.40 & $1.11-5.18$ & 0.026 \\
\hline \multicolumn{1}{c}{ Neisseria gonorrhoeae } & & & \\
Younger age (15-24 years) & 1.50 & $1.09-2.05$ & 0.012 \\
Urethral discharge upon physical examination & 9.92 & $5.53-17.70$ & 0.001 \\
Genital warts upon physical examination & 18.28 & $8.03-41.60$ & 0.001 \\
Genital ulcer upon physical examination & 4.90 & $1.06-22.73$ & 0.042 \\
\hline
\end{tabular}

\section{DISCUSSION}

This study sought to investigate the prevalence of Chlamydia trachomatis and Neisseria gonorrhoeae infections and assess associated risk exposures in men attending STD clinics in Brazil. Analysis of the results verified that $4.4 \%$ of men had both infections. The coinfection rate obtained was consistent with the results of previous studies conducted among the male population in Brazil ${ }^{11,12}$ and other countries ${ }^{8,14}$.

The isolated frequency of each infection reported in this study was high, as expected in an STD clinic, $13.1 \%$ and $18.4 \%$ of Chlamydia trachomatis and Neisseria gonorrhoeae, respectively. Since male gonococcal infections are largely symptomatic ${ }^{15}$, diagnostic testing, rather than routine screening, has been the recommended disease control strategy, and national disease rates in men reflect mainly symptomatic infection. Although there is evidence that asymptomatic gonococcal infections in heterosexual men may contribute disproportionately to disease transmission to women ${ }^{14}$, relatively few studies have measured the prevalence of Neisseria gonorrhoeae infection among asymptomatic men ${ }^{9,16,17}$. Regarding C. trachomatis infection, the rate of asymptomatic infection is higher ${ }^{18}$.

The main risk factors reported in the literature as associated with C. trachomatis infections are age below 25 years-old, inconsistent condom use, multiple sexual partners, a new partner in the preceding 60 days and a history of $S \mathrm{TD}^{11,19,20}$. In this study, an association among younger men (15-24 years-old) with infections was identified, but no association with reporting more than one partner in the preceding 12 months, inconsistent condom use and previous STD was included in the final model.

There is a lack of current evidence-based data for clinical symptoms and coinfection diagnosis in male populations ${ }^{4,8}$. An association between $C$. trachomatis infection and gonorrhea with urethral discharge was verified in this study. This it was an expected result even when considering that these infections can be asymptomatic in numerous cases ${ }^{18}$. An association between genital ulcer and genital vesicles and gonorrhea upon clinical examination 
was also verified. This can be explained by the fact that STD are frequently associated. It is important to highlight that STD are often transmitted through the same route and treating them may reduce the incidence of HIV and other STD, an important measure in prevention planning and care services ${ }^{21}$. Prevalence assessment and monitoring is an important component of STD control and both can be performed on vulnerable populations.

The limitations of this study include the distribution and the nature of the sample, which could limit inferences to other data in Brazil and the cross-sectional design, which precludes inferences concerning cause and effect. However, the response rate obtained was high and multicentric data are highly relevant and generalizable to men attending STD clinics in Brazil. Nevertheless, the Brazilian population is highly heterogeneous and inferences from this study may be limited regarding men attending primary health clinics or private health care. The possibility of response bias, owing to the tendency to provide socially acceptable answers, cannot be excluded. We suggest that such biases would result in the under-estimation of risky attitudes and behaviors. Inaccuracies of recall of condom use, age of first intercourse and number of sexual partners also may have occurred.

Besides the impact on C. trachomatis prevalence and associated morbidity among female partners, the cost of male screening for C. trachomatis and N. gonorrhoeae is in large part determined by the ease of access to males who are shown to be at high risk of these infections ${ }^{2}$. This forms the rationale for a venue-based approach in which men in specific venues, with demonstrated high rates of these infections, such as the STD clinic population, are offered testing. The identification and treatment of sex partners is also a cornerstone of STD prevention efforts and reduces the risk of reinfection. Findings from this study have implications for education and prevention efforts, including routine counseling and diagnostic tests directed toward young men at risk of HIV/STD.

\section{ACKNOWLEDGMENTS}

The authors are grateful to the Brazilian National STD/AIDS Program and the German agence for technical cooperation (Deutshe Gesellschaft Fur Technische Zusammenabeit - GTZ) for supporting this study. The authors would also like to thank the researchers responsible for each clinic: Adele Schwartz Benzaken (Manaus); Telma Alves Martins (Fortaleza); Luiza Cromack (Rio de Janeiro); Elisabeth Taeko Onaga (São Paulo); Leticia Nolde Melo (Porto Alegre) and Isolina de Lourdes Rios Assis (Goiânia).

\section{CONFLICT OF INTEREST}

The authors declare that there is no conflict of interest.

\section{FINANCIAL SUPPORT}

Brazilian National Program of STI and AIDS and the German agence for technical cooperation (Deutshe Gesellschaft Fur Technische Zusammenabeit - GTZ).

\section{REFERENCES}

1. Rietmeijer CA, Hopkins E, Geisler WM, Orr DP, Kent CK. Chlamydia trachomatis positivity rates among men tested in selected venues in the United States: a review of the recent literature. Sex Transm Dis 2008; 35(11):S8-S18.

2. Gift TL, Gaydos CA, Kent CK, Marrazzo JM, Rietmeijer CA, Schilinger CA et al. The program cost and cost-effectiveness of screening men for Chlamydia to prevent pelvic inflammatory disease in women. Sex Transm Dis 2008; 35(suppl 11):S66-75.

3. Stamm W. Chlamydia screening: Expanding the scope. Ann Intern Med 2004; 141:570-572.

4. Workowski KA, Berman SM. Centers for Disease Control and Prevention. Sexually transmitted diseases treatment guidelines. MMWR Recomm Rep 2006; 55(RR-11):1-94.

5. Stamm WE. Chlamydia trachomatis infections of the adult. In: Holmes KK, Mardh PA, Sparling PF, Lemon SM, Stamm WE, Piot P, et al, editors. Sexually Transmitted Disease. $3^{\text {rd }}$ ed. United States: McGraw-Hill; 1999. p. 407-422.

6. Turner CF, Rogers SM, Miller HG, Miller WC, Gribble JN, Chromy JR, et al. Untreated gonoccoccal and chlamydial infection in a probability sample of adults. JAMA 2002; 287:726-733.

7. Peterman TA, Tian LH, MetcalfCA, Satterwhite CL, Malotte CK, DeAugustine N et al. High incidence of new sexually transmitted infections in the year following a sexually transmitted infection. Ann Intern Med 2006; 145:564-572.

8. Gaydos CA, Kent CK, Rietmeijer CA, Willard NJ, Marrazzo JM, Chapin JB, et al. Prevalence of Neisseria gonorroeae among men screened for Chlamydia trachomatis in four United States cities, 1999-2003. Sex Transm Dis 2006; 33:314-319.

9. Cecil JA, Howell MR, Tawes JJ, Gaydos JC, McKee-Jr KT, Quinn TC, et al. Features of Chlamydia trachomatis and Neisseria gonorrhoeae infection in male Army recruits. J Infect Dis 2001; 184:1216-1219.

10. Lyss SB, Kamb ML, Peterman TA, Moran JS, Newman DR, Bolan G, et al. Chlamydia trachomatis among patients infected with and treated for Neisseria gonorrhoeae in sexually transmitted disease clinics in the United States. Ann Intern Med 2003; 139:178-185.

11. Fioravante FC, Costa Alves Mde F, Guimarães EM, Turchi MD, Freitas HA, Domingos LT, et al. Prevalence of Chlamydia trachomatis in asymptomatic Brazilian military conscripts. Sex Transm Dis 2005; 32:165-169.

12. Castro CRC, Passos MRL, Pinheiro VMS, Barreto NA, Rubenstein I, Santos CCC. Detecção de Chlamydia trachomatis em homens militares com queixas clínicas de uretrite. DST J Bras Doencas Sex Transm 2000; 12:4-11.

13. Ministério da Saúde. Secretaria de Projetos Especiais de Saúde. Coordenação de Doenças Sexualmente Transmissíveis e AIDS. Manual de Controle das Doenças Sexualmente Transmissíveis. Brasília; 1999.

14. Khan A, Fortenberry JD, Juliar BE, Tu W, Orr DP, Batteiger BE. The prevalence of Chlamydia, Gonorrhea, and Trichomonas in sexual partnerships: implications for partner notification and treatment. Sex Transm Dis 2005; 32:260-264.

15. Hook EWI, Handsfield HH. Gonococcal infections in the adult. In: Holmes KK, Mardh PA, Sparling PF, Lemon SM, Stamm WE, Piot P, et al, editors. Sexually Transmitted Disease. $3^{\text {rd }}$ ed. United States: McGraw-Hill; 1999. p.451-466.

16. Miller WC, Ford CA, Morris M, Handcock MS, Schmitz JL, Hobbs MM, et al. Prevalence of chlamydial and gonococcal infections among young adults in the United States. JAMA 2004; 291:2229-2236.

17. Arcari CM, Gaydos JC, Howell MR, McKee KT, Gaydos CA. Feasibility and short-term impact of linked education and urine screening interventions for chlamydia and gonorrhea in male army recruits. Sex Transm Dis 2004 31:443-447.

18. Schillinger JA, Dunne EF, Chapin JB, Ellen JM, Gaydos CA, Willard NJ, et al Prevalence of Chlamydia trachomatis infection among men screened in 4 U.S cities. Sex Transm Dis 2005; 32:74-77.

19. LaMontagne DS, Fine DN, Marrazo JM. Chlamydia trachomatis infection in asymptomatic men. Am J Prev Med 2003; 24:36-42.

20. Hiltunen-Back E, Haikala O, Kautiainen H, Paavonen J, Reunaia T. A nationwide sentinel clinic survey of Chlamydia trachomatis infection in Finland. Sex Transm Dis 2001; 28:252-258.

21. Fleming DT, Wasserheit JN. From epidemiological synergy to public health policy and practice: the contribution of other STD to sexual transmission of HIV infection. Sex Trans Infect 1999; 75:3-17. 